\title{
SANTOS DUMONT: UM POETA A VOEJAR
}

\section{SANTOS DUMONT: A POET TO FLY}

\author{
Lucília Maria Abrahão e SOUSA ${ }^{1}$ \\ Taísa Mara Pinheiro SILVA² \\ Bruno MONTEIRO ${ }^{3}$ \\ João Flávio de ALMEIDA ${ }^{4}$
}

\section{RESUMO}

Filiados à Análise do Discurso, conforme proposta por Michel Pêcheux, pretendemos verificar as discursividades que se encontram e confrontam na exposição "Poeta dos ares, Santos Dumont", realizada pelo Museu do Amanhã na cidade do Rio de Janeiro. Tal evento foi mobilizador de sentidos que historicamente já foram inscritos e falados em outro lugar antes e que materializaram sentidos poéticos da obra e vida do célebre inventor brasileiro, Santos Dumont. Pretendemos identificar os efeitos discursivos colocados em circulação por suas invenções - poesia, que se fez (com) corpo - e entender que deslocamentos e desarranjos a exposição promoveu ao empreender voos até então inimagináveis para a humanidade. E, precisamente, no inimaginável que nos concentramos para tratar da figura excêntrica, persistente e idealista de nosso inventor. Quais os efeitos discursivos de suas decolagens? De que maneira a trajetória dele transgrediu o comum e inscreveu, com insígnia de poeta, seu nome pelos ares? Nosso escrito é uma tentativa de resposta às questões aqui mencionadas.

PALAVRAS-CHAVE: Discurso; Santos Dumont; Linguagem; Deslocamentos; poético.

\begin{abstract}
Inscribed in the Discourse Analisys, as proposed by Michel Pêcheux, we intend to verify the discursive effects that approach and are confronted in the exhibition "Poet of the air, Santos Dumont", realized by the Museum of the Tomorrow, in the city of Rio de Janeiro. This event was a mobilizer of meanings that have historically been inscribed and spoken elsewhere before and have materialized the poetic senses of the work and life of the famous Brazilian inventor, Santos Dumont. We intend to identify the discursive effects put into circulation by his inventions - poetry, which was made (with) body - and understand that displacements and disarrangements the exposure promoted when undertaking flights hi ther to unimaginable for humanity. It isprecisely in the unimaginable that we concentrate to deal with the eccentric, persistent and idealistic figure of our inventor. What are the discursive effects of your take offs? In what way did his trajectory transgress the common and inscribed, with the insignia of a poet, his name through the air? Our writing is anattempt to answer the questions mentioned here.
\end{abstract}

KEYWORLDS: Discourse; Santos Dumont; Language; Displacements; poetic.

\section{INTRODUÇÃO: EFEITOS DE UMA DECOLAGEM}

Voar é com os poetas (Museu do Amanhã, 2017)

\footnotetext{
${ }^{1}$ Doutora. USP/Ribeirão Preto. luciliamasousa@gmail.com

2 Mestranda. PUC/Minas. ta pinheiro@hotmail.com

${ }^{3}$ Mestrando. USP/Ribeirão Preto. brunomonteiro_h@live.com

${ }^{4}$ Doutor. USP/Ribeirão Preto e UNAERP. joaoflaviodealmeida@gmail.com
} 
Caminhando pelo chão teórico da Análise de Discurso (AD) fundada pelo filósofo francês Michel Pêcheux, que em seu ensino postulou o discurso como "efeito de sentidos entre interlocutores" (PECHEUX, 1969, p. 84), tem-se como objetivo nesse estudo, compreender os discursos materializados pela / na exposição "Santos Dumont, o poeta voador", tomada aqui como objeto de nossa análise. Pêcheux ([1975] 2014) descreve o discurso como uma prática linguageira que produz sentidos para e por sujeitos, constituindo um dizer em curso, dis-curso, movência da língua, que viabiliza tanto a estabilidade quanto o deslocamento dos sentidos que poderá transformar o homem e sua realidade (ORLANDI, 2007). Desse modo, os sentidos não são estanques, eles podem tornar-se outros, desfazendo as noções de literalidade e obviedade dos sentidos.

Nesses termos, a AD considera que linguagem e ideologia constituem-se mutuamente deixando marcada a língua e o sujeito. Língua inscrita na história para que haja sentido, à vista disso, na relação pensamento-linguagem-mundo sempre há uma abertura e que será nessa brecha que o processo discursivo será regido e determinado ideologicamente, processo que acaba por interpelar todo indivíduo em sujeito de seu discurso (ORLANDI, 2007). Destacamos nossa posição como analistas de discurso, que visa a tomar a língua em sua mobilidade para, assim, observar os sujeitos falando, silenciando e produzindo sentidos. Assim, não tomamos aqui a exposição como um mero conglomerado de imagens e textos, mas sim como discursividade, ou seja, em seu funcionamento e como ela produz sentidos.

Para isso, tomamos o nome próprio de Alberto Santos Dumont como algo a ser estranhado e atravessado para além do que poderia estar posto nele como naturalidade e obviedade. Nosso percurso atravessa alguns efeitos de sentido que, da biografia sobre o aviador e dos seus depoimentos autobiográficos, deslocam-se para o interior da Exposição Temporária do Museu do Amanhã (doravante MA), nomeada como "O poeta voador, Santos Dumont", cujo objetivo era apresentar o inventor como um jovem cientista e empreendedor, destacando o lado poético e artístico de Dumont, colocando-o como um "homem de ciências que se inspirava na arte" (MUSEU..., 2017, pág. web). Ainda destacamos que Alberto Dumont foi um visionário que possibilitou transformar o verbo voar em "uma ação técnica plausível" (MUSEU..., 2017, pág. web). Vejamos alguns dados do navegador dos ares.

Alberto Santos Dumont nasceu na Fazenda Cabangu/João Gomes (hoje Santos Dumont) em Minas Gerais, em 1873, e faleceu na cidade do Guarujá, em São Paulo no ano de 1932. O filho do francês Henrique Dumont e da brasileira Francisca Santos Dumont era descrito como uma criança solitária e sonhadora, desde cedo já fascinada pelas máquinas as quais parecia preferir à companhia familiar de seus pais e irmãos. No ambiente interiorano em que vivia, ao contrário dos irmãos, não era dado à caça, nem aos passeios a cavalo, fascinava-lhe, sobretudo, a tecnologia que ele também ali na fazenda de seu pai teve oportunidade de vivenciar. Apelidado de o "Rei do Café", a fazenda de seu pai era uma das maiores do país e toda equipada com aparatos tecnológicos para realizar desde a colheita do café, seu armazenamento até seu escoamento, visto que ele também cuidou da construção uma estrada de ferro com 96 quilômetros de comprimento para percorrê-la (HOFFMAN, 2010, p.13). Alberto conhecia minuciosamente todos os processos de produção do café e interessava-se pelas maquinarias, seus funcionamentos e se dispunha a consertá-las com alguma frequência. Sua curiosidade, aliada a um gosto vivo pela literatura, além da influência de seu pai engenheiro que deixava às vistas seus livros técnicos, confluíram para sua construção de seu mundo lúdico e singular desde muito cedo.

\footnotetext{
5“O poeta Voador, Santos Dumont”, Exposição temporária apresentada no Museu do Amanhã, entre 26 de abril de 2018 à 19 de fevereiro de 2017. Realização: Fundação Roberto Marinho. Curadoria: GrincoCardia. Consultoria científica: Henrique Lins de Barros.
} 
Os livros favoritos eram de ficção científica. Ele gostava da imagem de Júlio Verne de um céu povoado de máquinas voadoras e, aos 10 anos, já tinha lido todos os seus romances. Aprendeu nos livros de engenharia do pai que o balão de ar quente fora inventado em 1783, por Joseph e EtienneMontgolfier(...) Os irmãos Montgolfier construíram um grande invólucro em forma de pera, de papel e seda, com uma abertura na base para ser inflado com a fumaça de palha queimada. Um relato dizia que a inspiração viera quando Joseph jogou despropositadamente uma embalagem cônica de papel de pão doce na lareira e surpreso a viu subir na chaminé sem queimar.” (HOFFMAN, 2010, p.15)

Júlio Verne foi uma grande influência para o pequeno Santos Dumont em uma época em que a única maneira de voar era por balões de hidrogênio ou de ar quente e, ainda assim, apenas na distante Europa. O garoto, que só veria um voo tripulado de um balão aos quinze anos, já estava convencido pela literatura fantástica de Verne de que os balões haviam sido superados e as pessoas já voavam em dirigíveis, em balões motorizados, o Albatroz, segundo a obra de Verne (HOFFMAN, 2010, p 19). Tais dados biográficos são relevantes para observarmos o modo como esse menino curioso e atravessado pela ficção do "grande vidente" está atento a uma realidade de "locomoção aérea e submarina", ou seja, os efeitos de um mundo de palavras e $(\mathrm{m})$ movimentos passam a tomar a curiosidade intelectual e o espírito prático do modo como é posto por ele mesmo.

\begin{abstract}
"As primeiras lições que recebi de aeronáutica foram-me dadas pelo nosso grande visionário: Júlio Verne. De 1888, mais ou menos, a 1891, quando parti pela primeira vez para a Europa, li, com grande interesse, todos os livros desse grande vidente da locomoção aérea e submarina. Algumas vezes, no verdor dos meus anos, acreditei na possibilidade de realização do que contava o fértil e genial romancista; momentos após, porém, despertava-se, em mim, o espírito prático, que via o peso absurdo do motor a vapor, o mais poderoso e leve que eu tinha visto.” (DUMONT, 1918)
\end{abstract}

Em sua primeira viagem à Paris é que Alberto vai experimentar o que sua imaginação havia apenas esboçado até então. Espantado de não haver na Cidade Luz do final do século XIX, tão esfuziante com as novidades da torre Eiffel, dos carros que não deixavam as ruas cheirarem a cavalo e dos telefones que permitia a comunicação instantânea, as naves voadoras que lhe habitaram a infância. Havia apenas os balões a gás ou a hidrogênio, dos quais não se podia controlar o trajeto e, não raro, levavam as pessoas a terras distantes. Foi em um desses exemplares que ele teve sua primeira experiência de voo; Hoffman (2010, p. 29) coleta as impressões narradas por Santos Dumont e que soam bastante literárias.

No mesmo instante, o vento deixou de soprar. Era como se o ar em volta de nós tivesse se imobilizado. É que havíamos partido, e a corrente de ar que atravessávamos nos comunicava sua própria velocidade. Eis o primeiro grande fato que se observa quando se sobe num balão esférico. Esse movimento imperceptível de marcha possui um sabor infinitamente agradável. A ilusão é absoluta. Acreditar-se-ia, não que é o balão que se move, mas que é a terra que foge dele e se abaixa (...) Sobre esse fundo de alvura imaculada, o sol projetava a sombra do balão; e nossos perfis, fantasticamente aumentados, desenhavam-se no centro de um triplo arco-íris. Pelo fato de não vermos a terra, toda noção de movimento deixava de existir para nós. Poderíamos avançar com a velocidade de um furacão sem nos apercebermos. Não tínhamos nenhum outro meio de conhecer o rumo tomado, senão descer e determinar nossa posição.

Nosso aviador acabara de vivenciar uma experiência mais leve que o ar. Em uma bela descrição, ele diz que lhe foi possível experimentar a sensação de estar suspenso no vácuo, em que a gravidade não mais lhe rondava o corpo e, naquele momento, sentira-se como um prisioneiro do nada opaco. (HOFFMAN, 2010, p 29). Decidiu, a partir de então, que sua missão seria desenhar uma máquina voadora propulsionada por um motor de combustão 
interna que não ficasse à deriva em terras distantes. Após diversas ascensões em balões e dirigíveis, e arriscar a vida pelo progresso aeronáutico - com o espírito tomado pelo otimismo científico da época que fazia nobres aqueles que se auto sacrificavam em prol de conquista maiores para a humanidade, é que, em 1906, o Bis alçou voo. Naquele momento, após quedas míticas e uma fama que já se alastrara, a imagem de Santos Dumont figurava até mesmo pães de mel vendidos na Champs- Elysée. Seu projeto número 14, a aeronave 14, era o primeiro avião e a única máquina mais pesada que o ar a sobrevoar a Europa; assim, os jornais da época aclamaram-no como "Santos-Dumont o Conquistador do Ar!". Podemos dizer, nesses termos, que Albert Santos Dumont foi, ao mesmo tempo, um homem de sua época e um homem bastante à frente dela. Primeiro porque refletia e materializava ideias positivistas como, por exemplo, o otimismo na ciência como elemento que poderia, em seus progressos, colocar um fim ao sofrimento humano. Em segundo lugar, é possível dizer que a sua personalidade idealista, empreendedora e excêntrica colocou em movimento a capacidade de sonhar e ousar.

\begin{abstract}
A história de Ícaro e de mitos similares nas culturas asiáticas e africanas mostra que o fascínio pelo voo humano foi universal e remonta à Antiguidade. Existem diversas lendas sobre homens alados, mas não há mitos sobre pessoas ascendendo ao céu em máquinas similares a balões. Essa diferença pode ser explicada pelos exemplos oferecidos no mundo natural. Com a exceção de bolhas efervescentes ocasionais, há poucos exemplos de objetos esféricos transportados pelo ar, porém existe uma abundância de aves mais pesadas que o ar batendo as asas no céu. (HOFFMAN, 2010, p 57)
\end{abstract}

A invenção de Santos Dumont pode ser colocada em litoral como o discurso poético, tomando a poesia não como o excepcional da língua, mas como seu próprio (PÊCHEUX, 1990 [1982]). O pai da (a)via(inova)ção, como um poeta, faz torção com os sentidos estabilizados, prov(oc)ando que alguma coisa mais pesada que o ar possa se sustentar, deslocar-se e voar, algo considerado impossível para sua época. Desse modo, é na possibilidade de desarranjar sentidos tidos como óbvios e como o estável, que uma invenção pode ser tomada como o poético da língua, do sujeito e da ciência. Santos Dumont, com sua perícia, fez da ciência, engenharia e tecnologia, poesia; pois, transformou o "estatuto humano, de pedestre a pássaro" (Museu..., 2017, pág. web), deslocou os sentidos possíveis para o estado humano e o (e)levou para os ares. Seria uma viagem do ontem para o amanhã, do velho ao novo?

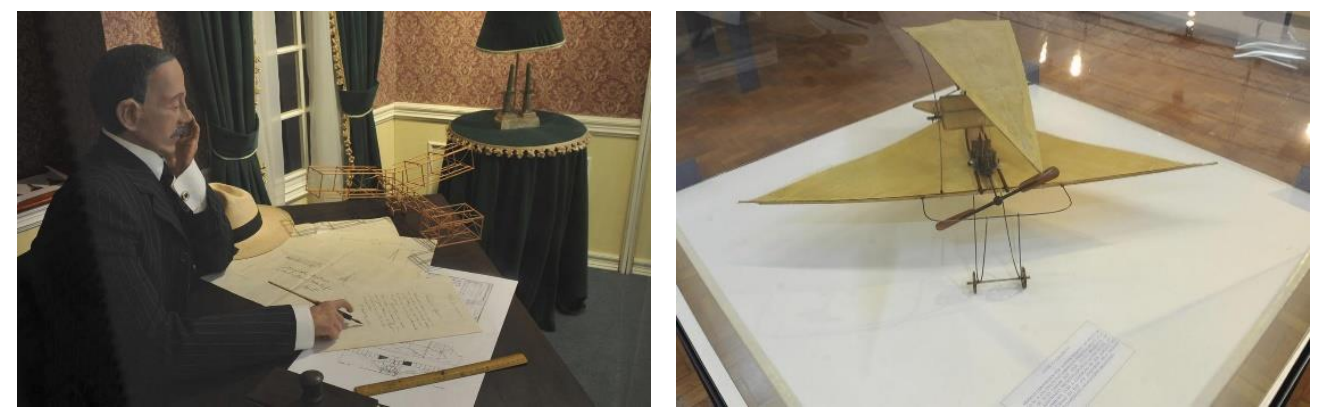

Imagens 1 e 2: Fotos da exposição.

Fonte: “O poeta voador, Santos Dumont” (Museu do Amanhã, 2017, pág. web)

Partindo disso, teceremos algumas palavras sobre a inscrição do Museu do Amanhã como efeito de sentidos de novo e de novidade, apontando para um futuro, tempo esse que se atribui ao que Dumont visionou a partir da ficção científica e colocou em movimento em seus escritos, desenhos e protótipos Assim, intentamos indagar como (e se) o legado de Dumont, nomeado como "o poeta voador", voa através dos ventos e traz novos ares, avistando ao horizonte um porvir. Que ares são esses? Quais os efeitos de sentidos 
produzidos nessa discursividade? Um poeta voador, no Amanhã, funciona como um respiro? Um sopro? Para decolarmos na tentativa de responder tais questões, estudamos o livro "O que eu vi o que nós veremos", de autoria de Santos Dumont. Objetivamos colocar a voz dele em paralelo com as noções de memória discursiva, condições de produção e formação discursiva, puxando alguns fios do discurso que atravessam os dizeres sobre o aviador e sua ciência, sobre o poético e sobre o amanhã.

\section{A ruptura do poético: quando voar tem maquinaria}

"Poesia é voar fora da asa." Manoel de Barros

Poderíamos definir poesia como um gênero literário caracterizado pela composição em versos estruturados de forma harmoniosa, ou mais, uma manifestação de beleza e estética retratada pelo poeta em forma de palavras. É possível ainda apresentar a proposição de que o poético constitui o funcionamento de toda língua, já que ela é plástica o bastante para produzir reviramentos imprevisíveis, equívocos e jogos de sentidos. Ou poderíamos tentar poetizar: "poesia é voar, voar com asas feridas através de palavras escondidas, voejar", tal como o poeta pantaneiro escreveu. Muitos se dedicam a esquadrinhar, delinear e definir poesia, outros tantos colocam-se apenas a nela mergulhar, despreocupados com os limites imprecisos desse oceano chamado língua. De fato, a complexidade de se encontrar uma definição menos movente para arte e poesia pode decorrer justamente do fato de que não há arte, tampouco poesia.

\footnotetext{
Uma coisa que realmente não existe é aquilo a que se dá o nome de Arte. Existem somente artistas. Outrora, eram humanos que apanhavam terra colorida e modelavam toscamente as formas de um bisão na parede de uma caverna; hoje, alguns compram suas tintas e desenham cartazes para os tapumes; eles faziam e fazem muitas outras coisas. Não prejudica ninguém chamar a todas essas atividades arte, desde que conservemos em mente que tal palavra pode significar coisas muito diferentes, em tempos e lugares diferentes, e que Arte com A maiúsculo não existe. Na verdade, Arte com A maiúsculo passou a ser algo de um bicho-papão e de um fetiche. Podemos esmagar um artista dizendo-lhe que o que ele acaba de fazer pode ser muito bom no seu gênero, só que não é "Arte". E podemos desconcertar qualquer pessoa que esteja contemplando com prazer um quadro, declarando que aquilo de que ela gosta não é Arte, mas algo muito diferente (GOMBRICH, 1999, p.11, grifo nosso).
}

Quem está dizendo que "Arte não existe" é ninguém menos que Ernst Hans Josef Gombrich, um dos mais célebres historiadores da arte. Ele inicia sua obra magna afirmando que arte é só uma palavra, e que "pode significar coisas muito diferentes, em tempos e lugares diferentes". Impossível não ouvir os ecos da Análise do Discurso de Michel Pêcheux (2008, 2009), que conceitua a própria significação em termos parecidos, como confluência errante de língua, história e sujeito. Esse olhar discursivo para a arte nos impele, portanto, a considerar os efeitos materiais da arte enquanto trabalho discursivo, que produz efeitos na sociedade, nos sujeitos e na história. Em outras palavras, a falta de fundamentos naturais ou metafísicos para a arte não implica sua morte ou inexistência. Implica, sim, os movimentos errantes de uma palavra que, justamente por ser inacabada, perambula e se atualiza. A arte é um efeito discursivo, e isso não é pouco. Quando olhamos para os enunciados da estética sobre o belo ou sobre a valoração filosófica ou crítica da arte, observamos sentidos sendo trabalhados e posições-sujeito sendo estabelecidas. Em outros termos, é na soma errante de todos esses sentidos sobre a arte que podemos apreendê-la, ainda que de forma imprecisa e movente.

A arte pode assumir formas e importâncias diferentes para distintas áreas de conhecimento, mas partindo da Análise do Discurso, especificamente de Pêcheux, somos 
levados a assumir que a arte é mero efeito discursivo. A concepção de arte enquanto efeito discursivo, e obra de arte enquanto mera materialidade significante cujos sentidos são atribuídos de forma ideológica, histórica e política, impele-nos a assumir que sentido e sujeito (para a arte) são constituídos mutuamente de forma discursiva. E não há nada de sobrenatural nisto. Com a poesia dá-se o mesmo. Essa discussão é feita por Pêcheux principalmente na obra "A língua inatingível", (GADET E PÊCHEUX, 2004); nela, ele e Gadet estão às voltas em argumentar que a língua perfeita é uma estrutura inatingível. Um dos diálogos estabelecidos nessa obra é com Jean-Claude Milner, com sua obra "O amor da língua" (1987) e, no centro dessa discussão sobre o real da língua e sua impossibilidade de tudo dizer, está a poesia.

Em L'amour de la langue, em que a indissociabilidade dos dois Saussure é,
entretanto, reconhecida, a tese saussuriana do valor não é aplicada. Isso poderia
ser o corolário da posição sustentada por Milner em relação ao equívoco, cuja
percepção ele restringe ao "ponto de poesia" e algumas coincidências felizes com
as escritas eruditas: sem a poesia, afirma ele, nós não teríamos a ideia de que a
língua se inscreve no real, e os trocadilhos, lapsos etc. seriam acidentes. (GADET
E PÊCHEUX, 2004, p. 63).

A poesia, para Milner, assume certo protagonismo no que tange ao reconhecimento de que a língua se inscreve a partir do real, do non-sense e que o simbólico é incapaz de alcançar, e é justamente por isso que à língua é impossível tudo dizer. No entanto, na argumentação do autor, a poesia acaba assumindo um protagonismo do qual Pêcheux discorda.

\begin{abstract}
Mas de onde vem essa certeza sobre o lugar da poesia, ponto privilegiado de cessação? Poder-se-ia também entender, sob o princípio saussuriano do valor, que a poesia não tem lugar determinado na língua porque ela é literalmente coextensiva a esta última, do mesmo modo que o equívoco: talvez 'não haja poesia' (GADET E PÊCHEUX, 2004, p. 64).
\end{abstract}

Segundo a leitura que Pêcheux faz de Milner, o poético é um funcionamento à parte na língua que, como um romântico, crê na possibilidade de se reparar os erros da língua sem que houvesse algum dano ao fazer poético da arte. Por isso ele atribui um peso muito importante a este "ponto de poesia", que seria o local teórico no qual a língua fecha sua dobra, um lugar de cessação. O problema, afirma Gadet e Pêcheux, é que Milner não pressupõe em sua argumentação a noção de valor do signo ${ }^{6}$, o que o leva a afirmar que a linguagem poética é uma linguagem à parte com um funcionamento exclusivo (GADET E PECHEUX, 2004, p.63). Gadet e Pêcheux discordam dele, apontando que quando o conceito de valor é inserido nessa equação, essa certeza da poesia como um ponto privilegiado de cessação perde sua sustentação. Compreender a língua sob o princípio do valor nos leva a assumir que:

(...) a poesia não tem lugar determinado na língua porque ela é literalmente coextensiva a esta última, do mesmo modo que o equívoco: talvez não haja poesia. Não há poesia porque o que afeta e corrompe o princípio da univocidade na língua não é localizável nela: o equívoco aparece exatamente como o ponto em que o impossível (linguístico) vem aliar-se à contradição (histórica), o ponto em que a língua atinge a história (GADET E PÊCHEUX, 2004, p.64).

A poesia, portanto, é apenas uma das muitas formas de se fazer uso da língua. Podese, por exemplo, fazer um uso científico da língua, negociando imaginariamente (e ilusoriamente) sua relação de oposição com a loucura. Esquecemos, assim, "que a loucura (e

${ }^{6}$ Em Saussure, a noção de que um signo vale em relação (de oposição) aos outros. 
a poesia) fazem também um certo uso da língua, são igualmente apreendidas no real" (GADET E PÊCHEUX, 2004, p.63). Logo, "não existe língua científica pura" (PÊCHEUX, 2009, p. 182), ou melhor, não existe língua fora da ideologia: nem científica, tampouco poética. Se para Gombrich não há arte, para Pêcheux "não há poesia". Em nosso texto, isso significa assumir que arte e poesia são efeitos discursivos que nada possuem de sobrenatural, transcendental, essencialmente divino, romântico ou mais verdadeiro que outros usos da língua, afinal, em Pêcheux toda a língua está sujeita, em seu funcionamento, a deslizamentos e rupturas em sua relação com o impossível.

\begin{abstract}
Diante das teorias que isolam o poético do conjunto da linguagem, como lugar de efeitos especiais, o trabalho de Saussure [...] faz do poético um deslizamento inerente a toda linguagem: o que Saussure estabeleceu não é uma propriedade do verso saturnino nem da poesia, mas uma propriedade da própria língua. O poeta seria apenas aquele que consegue levar essa propriedade da linguagem a seus últimos limites (GADET E PECHEUX, 2004, p.58).
\end{abstract}

Toda linguagem carrega uma potência poética inerente e o poeta é apenas aquele que joga com as características errantes do sentido. Nesse aspecto, toda a linguagem que atravessa e impregna os objetos simbólicos e gestos humanos pode funcionar investida de poesia. Quando ciência, política, religião e outros pretendem uma língua estável e inequívoca, é preciso que se trabalhe para anular a "poesia imanente" do signo, sua errância incorrigível. É neste batimento entre sedentarização e errância que se situa a linguagem imaginativa de Santos Dumont.

\title{
A ciência poética de Santos Dumont: efeitos de voo
}

"Eu penso renovar o homem usando borboletas" Manoel de Barros

A inspiração de voar veio das histórias de Júlio Verne e, por elas, o inventor ousou imaginar que aquelas fantasias poderiam se tornar realidade (PIQUEIRA, 2008); foi justamente esse caráter poético, que perpassava as criações de Santos Dumont, que foi retratado na exposição "O poeta voador, Santos Dumont". A inventividade do gênio advinha de sua capacidade de romper com as amarras ideológicas da língua que já em sua época tratava de estabilizar, administrar e apoucar o sentido, o sujeito e o mundo. É justamente a partir dessa posição de inventor que o poeta voador será apresentado: "a capacidade do inventor brasileiro, um visionário que se dedicou à ciência e à tecnologia inspirado pela arte", afirma o texto da exposição do Museu do Amanhã. Observamos aqui um discurso que produz o remetimento ao universo das leituras feitas ainda na infância pelo menino e o modo como a literatura e a arte tocaram-no e provocaram-no a criar. 


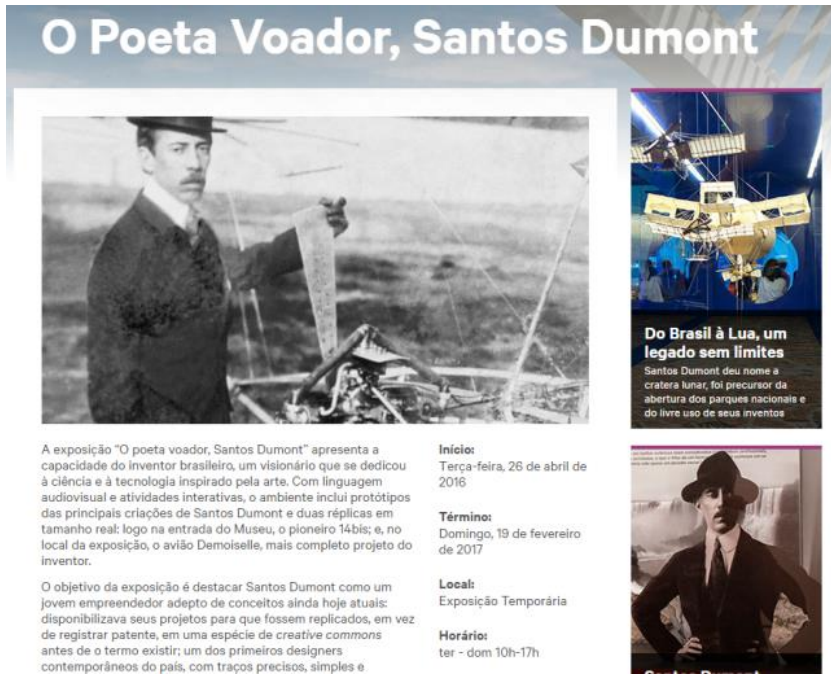

Imagem 3: Foto da página eletrônica da exposição.

Fonte: “O poeta voador, Santos Dumont” (Museu do Amanhã, 2017, pág. web)

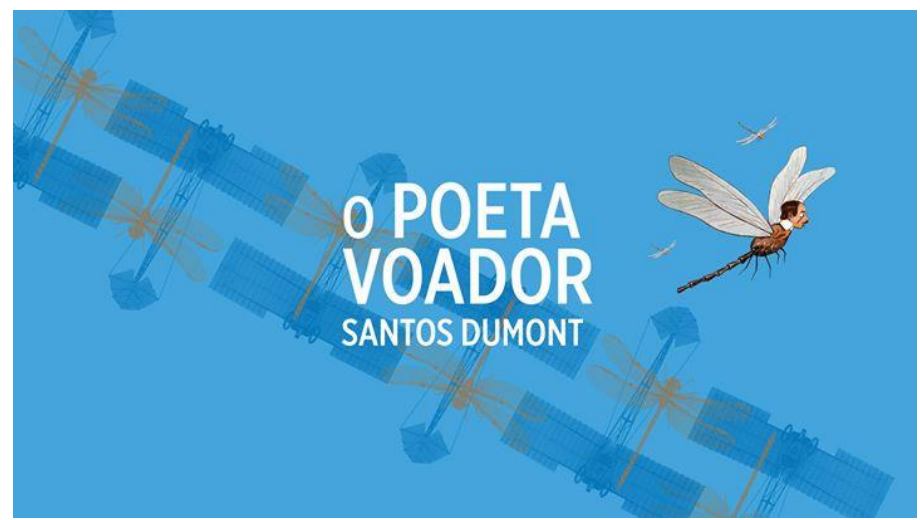

Imagens 4: Folder da exposição.

Fonte: Visita pessoal à exposição

A fotografia do folder da exposição constava de três línguas - português, inglês e espanhol - e apresentava um céu todo azul com uma figura híbrida, quase de ficção científica como nos livros de Verne em que uma libélula tinha o rosto de Dumont ou uma borboleta ou um outro inseto. Ou seria o inventor, que de tanto inventar-se, tornou-se o efeito de uma invenção? O poético faz movimentar a designação de "poeta voador", o que nos força a escutar a polissemia que aí pulsa: o poeta tem asas, o poeta é leve, o poeta voa, o poeta produz mesmo efeitos imprevisíveis, o poeta surpreende com a criação de algo que é meio humano e meio bicho, o poeta é ele mesmo uma obra rara. Uma figura no mínimo curiosa que, pelo efeito do reviramento dos estabilizados, permite um exercício de ousadia e assombro em que as asas se colam ao corpo de Santos Dumont. 


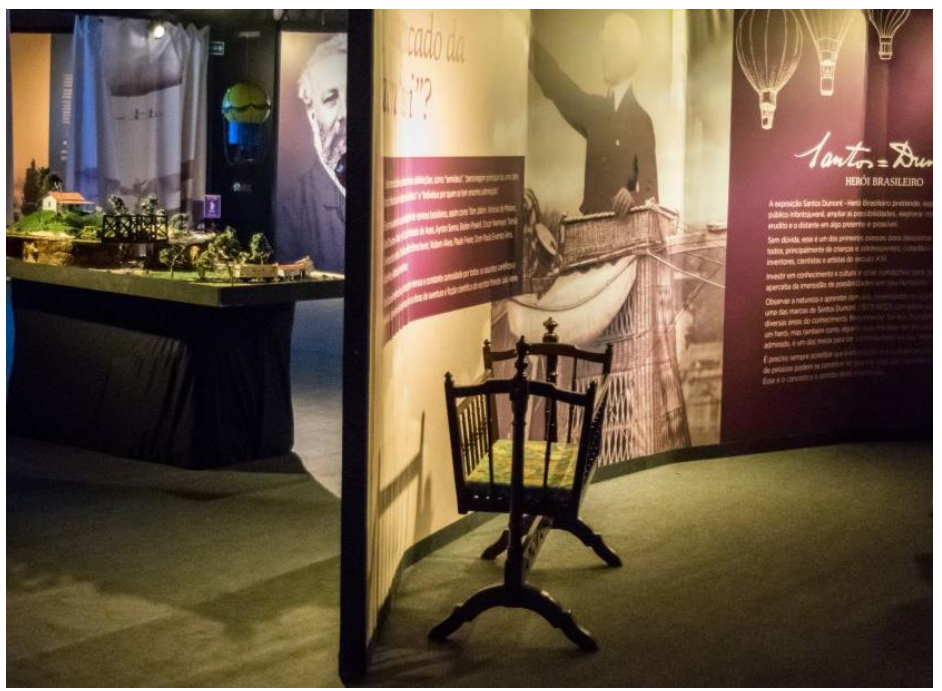

Imagem 5: Fotos da exposição.

Fonte: “O poeta voador, Santos Dumont” (Museu do Amanhã, 2017, pág. web)

O berço do bebê, tal como na fotografia acima, é solto e permite o balanço do corpo em uma espécie de capsula, como os balões que se seguem no painel. Temos aqui dois planos que se combinam: o móvel físico e o desenho. A realidade e a ficção outra vez combinadas de modo a produzir a continuidade entre dois mundos que se conjugam desde a infância de Dumont. O bercinho teria sido seu primeiro lugar de voar, de sentir-se balançar ao sabor do vento e de experimentar a leveza de inventar algo? Ora, sabemos pela teoria discursiva que as palavras não guardam seus sentidos estáticos e colados nelas mesmas; assim, um berço não tem o sentido fechado em si mesmo e aqui produz um deslocamento imenso do que é o berço como início da vida, do lugar de dormir como espaço de sonhar e desses dois pontos como condição para o voo do balão e das palavras.

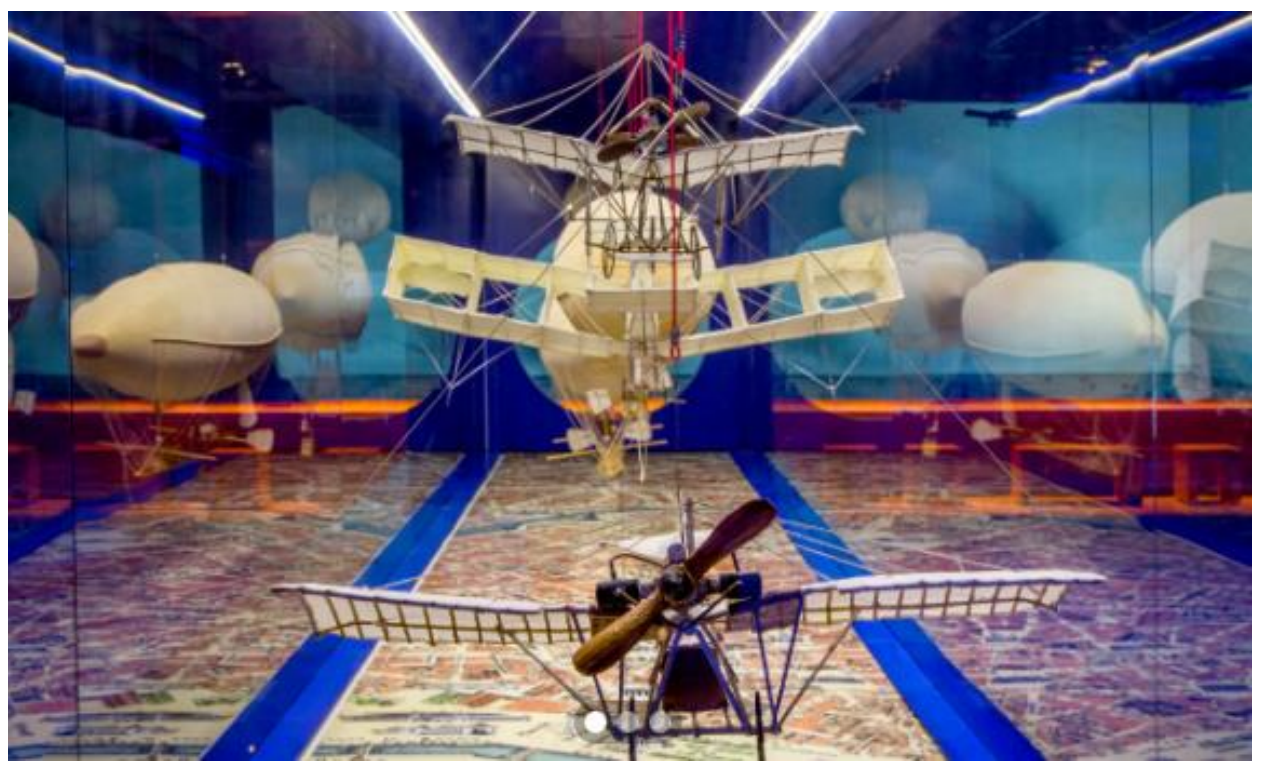

Imagens 6: Foto da exposição.

Fonte: “O poeta voador, Santos Dumont” (Museu do Amanhã, 2017, pág. web)

Os equipamentos desenhados e inventados por Dumont, os protótipos e as réplicas dos dirigíveis saídos do papel, o mapa de Paris no chão, os aviões modernos voando em um céu carioca já que o aeroporto central da cidade do Rio de Janeiro tem o nome do poeta 
voador: todos esses sentidos de/sobre voo entrecruzam-se em um céu de passado e presente, no qual pulsa o ineditismo da voz e dos inventos do poeta voador.

\title{
No amanhã, pássaros do progresso?
}

\author{
"Eu escuto a cor dos passarinhos" \\ Manoel de Barros
}

Os sentidos produzidos na/pela exposição "Santos Dumont, o poeta voador", apresentada no Museu do Amanhã dão pistas do inventor e pai da aviação a partir do próprio nome do museu, o tempo futuro. Para tanto, torna-se necessário tecermos algumas palavras sobre o museu e seu funcionamento, colocando em litoral com alguns conceitos teóricos da $\mathrm{AD}$, como as noções de memória, ideologia e condições de produção. Pelos sentidos estabilizados, um museu é lugar que abriga uma memória histórica de uma pessoa, uma região, uma instituição, uma cultura, um fato que foram destaques pela história mundial; desse modo, podemos tomar o museu como um espaço em que funcionam sentidos preservação e circula a exposição de uma memória que do que deve e precisa ser rememorado, preservado, lembrado e transmitido.

\begin{abstract}
O museu é um espaço ilusoriamente tomado como completo, pleno, absoluto, total, inteiro e concluso, como se toda a história estivesse ali contida e toda ela fosse pautada na verdade, na precisão e na exatidão e fosse, ainda, imaginariamente real, tangível e verídica. Acima de tudo, inquestionável e certa. Seria, então, um lugar que "guarda" tudo que deve/pode ser rememorado e que se constitui como o que deve ser lembrado, como materialidade para não ser esquecida, cujo objetivo é a preservação da memória pela história. (TEIXEIRA, 2017, p. 933).
\end{abstract}

Assim, o museu é considerado um lugar discursivo onde as noções de completude estariam inscritas como uma região fechada na qual a evidência se instalaria. $O$ funcionamento ideológico, consoante ao que Pêcheux ([1975] 2014) postulou, produz o efeito de naturalização de alguns sentidos e silenciamento de outros, isto é, a ideologia faz como que as palavras "queiram dizer o que realmente dizem" (PÊCHEUX, [1975], 2014, p. 146) e que uma suposta naturalidade (ou evidência óbvia) seja produzida na relação palavra/mundo e museu/objeto museificado. Tendo em vista que os discursos são matéria prima do sentido e do sujeito, não podemos descartar a exterioridade do dizer, ou seja, as condições de produção do discurso, o contexto imediato e sócio-histórico que afeta e que sustenta a circulação dos dizeres, ora mantendo ora rompendo com o já-dito, ora fraturando o já-lá do discurso e fazendo deslizar o que foi dito antes em outro lugar independentemente. Essa memória do dizer nada tem a ver com a memória individual e cognitiva da Psicologia, mas se relaciona com um passado que faz presença nos dizeres sem que saibamos (ROBIN, 2016), conferindo uma filiação de dizeres pela/na história, com a qual o sujeito irá esbarrar ao retomar sentidos que sustentam o seu dizer. Pêcheux (2010, p. 56) descreve que "nenhuma memória pode ser um frasco sem exterior", ou seja, o dizer só é possível sobre um já dito, para que nossas palavras tenham sentido, é imprescindível que elas já façam sentido (ORLANDI, 2007).

No museu, o efeito ideológico faz parecer evidente que um fato e uma história sejam transparentes, desconsiderando-se a opacidade e a incompletude da linguagem; assim, os objetos do acervo/da exposição são considerados a expressão pura e fiel da realidade. Assim, é preciso considerar que um museu traz, em sua materialidade, os rastros e as pegadas de sujeitos interpelados pela ideologia, além da historicidade como constitutiva de todos dizer museal. Nesses termos e tendo conhecimento do funcionamento da memória discursiva, o Museu do Amanhã pode operar ideologicamente na saturação de uma outra memória, a do ontem. Um ontem, consoante a Robin (2016, p. 31), que não é deixado à deriva, mas sim que 
ele é "regido, gerido, preservado, explicado, contado, comemorado ou odiado". Tomando o museu que tematiza o/um futuro, pode-se lançar alguns gestos de leitura no tocante ao modo como Santos Dumont é apresentado e discursivizado para os sujeitos que visitam a exposição, nomeado como "o poeta voador". Indagamos: quais sentidos são produzidos por meio de um voo? Ou de um poeta? Ou de um poeta voador? Que poesia e quantos efeitos de voo funcionam ao longo da exposição? Há outros dizeres possíveis que foram silenciados? O berço, o aparelho, as réplicas, os aviões, a pista de pouso no chão, o mapa, o chapéu: todos esses elementos inscrevem e convocam efeitos de voo, de ar, de céu, de espaço aberto, de poesia.

Remetemo-nos aqui ao livro "O que eu vi o que nós veremos" (1918), de autoria de Santos Dumont, em que o autor escreve "Estas notas são dedicadas aos meus patrícios que desejarem ver o nosso céu povoado pelos Pássaros do Progresso" (DUMONT, 1918, p. 1). Na obra, o aviador descreve sua tristeza e descontentamento ao ver a aeronáutica, ciência que ajudou a fundar e a desenvolver, ser usada na guerra, causando tantas mortes. No decorrer do livro, Dumont descreve seu percurso como inventor dos objetos voadores, dos balões até os aviões mais requintados para a época, de como foi taxado como louco, do reconhecimento mundial por sua determinação e criação, das vezes que colocou sua vida em risco, de seu sonho de "domínio dos ares pelo homem" (DUMONT, 1918, p. 14). Na parte "O que nós veremos", o autor pontua sua previsão desejosa de um futuro em que teríamos a união, o encontro de países distantes, um contato mais íntimo, assinalando que "Seremos mais fortes, nos nossos laços de compreensão e amizade" (DUMONT, 1918, p. 15). Nas palavras do aviador "Se o aeroplano, Srs., se tem mostrado tão útil na guerra, quanto mais não o deverá ser em tempos de paz?" (DUMONT, 1918, p. 16). O que está em jogo aqui é o efeito de um questionamento diante da potência dos "pássaros do progresso", invento que escapou ao controle do inventor e à leveza de seu experimento, sendo mobilizado para a destruição de cidades, campos e vidas humanas. Tal recorte é trazido aqui para tensionar os sentidos que poderiam ser tomados como homogêneos e completos quando pensamos na invenção da aviação, produzindo uma rachadura na estabilidade deles. Há aí efeito de um litígio e uma contradição entre a curiosidade e a ousadia do inventor e o uso político que se fez de sua produção.

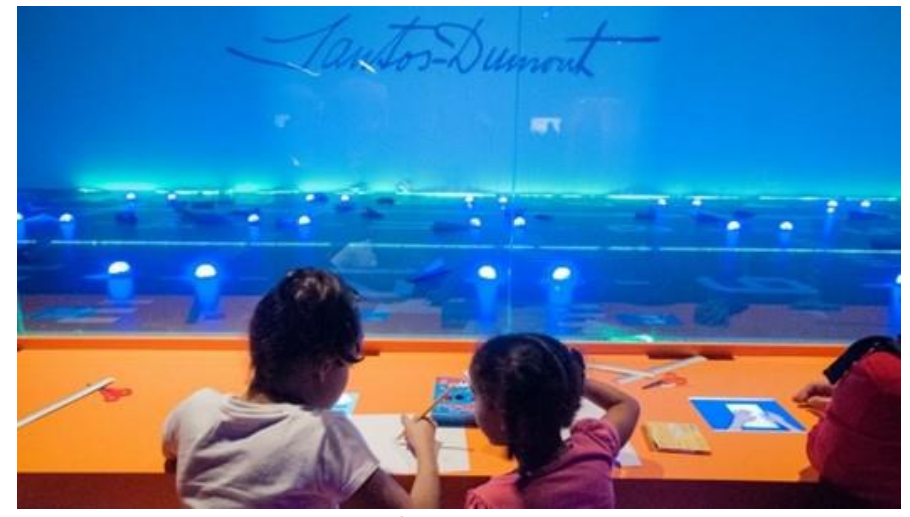

Imagem 7: Fotos da oficina "Aviões de papel” durante a exposição.

Fonte: “O poeta voador, Santos Dumont” (Museu do Amanhã, 2017, pág. web)

Sujeitos-crianças foram o mais importante público da exposição para os quais foram tecidos sentidos de brincadeiras em oficinas temáticas, contato com as invenções, a história e a vida do navegador dos ares. É interessante para essa reflexão compreender como tais efeitos funcionaram e circularam na exposição, o que nos convoca a questionar: de que futuro se trata? Estaria o progresso contido nas previsões de Santos Dumont? Um amanhã, que produz sentidos de um novo e/ou novidade, que tece no futuro união e empatia entre nações e povos, ou ao menos novos ares de esperança para a vida humana? Como a 
curiosidade infantil do menino interessado em Verne se manifestava deslocando-se da ficção científica para a realidade e afetando outros sujeitos infantis? A oficina de aviões de papel colocou em funcionamento diversas máquinas voadoras e seus sujeitos a dobrar e redobrar folhas de papel, tecendo uma metáfora visual de leveza e voo, de um relicário composto poeticamente enfim.

Hoje, nas atuais condições de produção, com a forma-sujeito capitalista neoliberal (ORLANDI, 2007; HAROCHE, 2010) muitas vezes silenciando o campo das artes, da poesia, o que o poeta voador poderia transmitir para o futuro dos sujeitos? Aos pássaros a deslizar pelos ares, que além de futuros empreendedores, homens e mulheres da ciência, poderão no sopro da língua, fazer poesia, ou seja, torcer os sentidos, desarranjar o óbvio, promover instabilidade nas paredes da evidência, promover giros nas palavras e, quiça, lançar dizeres outros que possam semear um amanhã de levezas.

\section{REFERÊNCIAS BIBLIOGRÁFICAS}

DUMONT, Alberto Santos. O que vi, o que veremos nós veremos. São Paulo: Domínio Público, 1918.

GADET, F; PÊCHEUX, M. A língua inatingível. Campinas, SP: Pontes, 2004.

GOMBRICH, E. H. A história da arte. 16. ed. Rio de Janeiro: LTC, 1999.

HAROCHE, C. Fazer dizer, querer dizer. São Paulo: Editora Haucitec, 1992.

HOFFMAN, P. Asas da Loucura: A extraordinária vida de Santos Dumont; tradução Marisa Motta. Rio de Janeiro: Objetiva, 2010.

MUSEU DO AMANHÃ. O poeta voador, Santos Dumont. Rio de Janeiro: Fundação Museu do Amanhã, 2017.

ORLANDI, E. Análise de Discurso. Princípios e procedimentos. Campinas: Pontes, 2007.

PÊCHEUX, M. (1969). Análise Automática do Discurso. In: GADET, F.; HAK, T. (Org.). Por uma análise automática do discurso: uma introdução à obra de Michel Pêcheux. Campinas, SP: Editora da UNICAMP, 2010.

PÊCHEUX, M. (1975). Semântica e discurso: uma crítica à afirmação do óbvio. 5. Ed. Campinas: Editora da Unicamp, 2014.

PÊCHEUX, M. O papel da memória. In: ACHARD, P. et al. O papel da memória. Tradução de José Horta Nunes. 3. ed. Campinas: Pontes, 2010.

PÊCHEUX, M. Semântica e discurso: uma crítica à afirmação do óbvio. 4. ed. Campinas, SP: Editora da Unicamp, 2009.

PIQUEIRA, G. Eu e os outros pioneiros da aviação. São Paulo: EscalaEducacional, 2008. ROBIN, R. A memória saturada. Campinas, SP: Editora Unicamp, 2016. 